\title{
Study on the Prohibition of the Purple Costumes in Ancient China
}

\author{
Xiaomeng $\mathrm{Qu}^{1}$ \\ ${ }^{1}$ Fashion, Art Design Institute, Donghua University, Shanghai, China \\ Correspondence: Xiaomeng Qu, Fashion, Art Design Institute, Donghua University, Room 201, No. 42, Lane \\ 5366, Hu Min Road of Minhang District, Shanghai 201100, China. Tel: 86-21-5415-4812. E-mail: \\ shelley1118@foxmail.com
}

Received: March 30, 2012

Accepted: April 21, $2012 \quad$ Published: July 1, 2012

doi:10.5539/ass.v8n8p134

URL: http://dx.doi.org/10.5539/ass.v8n8p134

\begin{abstract}
In ancient China, the color of the costumes was closely related to the social position of its wearer. It was such an intuitive and effective way to maintain the ruling order by distinguishing hierarchy according to the color of the costumes. As one of the important types of costume color in ancient China, the symbolic meaning of the color purple had went through the changes from the humble secondary color to a color representing honorable position. The prohibition on purple costumes had become an important part of the prohibitions in costumes in ancient China. This paper aims to probe into the transmission and changes about the prohibitions on purple costumes in ancient China by listing the regulations on wearing prohibition for its social members in different dynasties.
\end{abstract}

Keywords: Chinese traditional costumes, color, purple, prohibitions on costumes

\section{Introduction}

In the New York fashion week in Lincoln Center in 2011, Designer Wu Qingqing from China had come up with the VLOV S/S 2012 Collection. Purple is the dominant hue in her spring and summer collection, it is also the marking of the VLOV brand. "From east comes auspicious air, the fashion celebrities present speak highly of the oriental charm. Purple plays an important part in the traditional costumes. What kind of development changes had the symbolic meaning of purple gone through? Let us find it out by following the historical footprints.

\section{Sacred Color and Secondary Color}

In ancient China, advanced staining technique had been conducted early by employing mineral and vegetable dyes. Depending on the records in Rites of Zhou, since Zhou Dynasty, there were special official positions in charge of dyeing silk fabric. Ever since then, there had been special official positions in all dynasties. In Sui and Tang Dynasty, knitting and dyeing office was set with the eight ranks of public officials. In Ming and Qing Dynasty, special knitting and dyeing bureau was set. The advanced dyeing technique was marked with different colors in costumes for the rulers of the past dynasties to distinguish the rank of the social members. Then basis has been formed for establishing stable ruling order.

The color of the costumes not only had a sense of inheritance in the social rank represented in the successive costumes system, but also developed with dynasties, among which the developments of the purple costumes are the most typical.

The ancient rulers respected the saying about five elements, in which blue, red, yellow, white and black are the five primary colors, namely the sacred color, corresponding to the five elements wood, fire, earth, metal and water. Ever since the beginning of Xia Dynasty, colors of flags and clothes symbolized the ruling power, and most of the colors representing dynasty would be changed in time of the regime change. According to the ancient literature, Xia Dynasty advocated black, while Shang Dynasty favored white and Zhou Dynasty red. Till Qin Dynasty, in order to defeat Zhou Dynasty, it chose black. From Han Dynasty, Yellow had become a favorite color among the rulers.

Other colors that are mixed on the basis of the sacred color are called secondary color. For example, green is from mixing yellow with blue, light red is from mixing white and red, bluish green is from mixing green and white, dark is from mixing yellow and black and purple is from mixing blue and red. Sacred colors represent honorable status, which would be worn by people in a high social rank in ceremonial occasions, while secondary color is relatively humble. In Book of Rites, it is recorded the coats should be in sacred color, while the pants 
can be in secondary color. In Book of Songs, the sayings green coats and yellow skirts, the coat was in secondary color while the skirt was in sacred color, suggesting the chaos in the etiquette order. In Ritual Records System of King, it is said that it cannot be sold on the market when binary color replaces the sacred color. The binary color here means secondary color.

\section{The Developments of Purple Costumes}

At first, purple as one of the secondary colors represented a humble status. In Confucius' The Analects of Confucius Yang Huo, it is said that I hate the way purple spoils vermilion. It regards the color purple as a color that has a negative impression according to the order of the costume color. It is opposite to the sacred color red and it reflects dissatisfaction with the general mode of society in which the evil takes the place of the just. Even the informal dress cannot be purple. In the Xiangdang chapter of the Analects of Confucius, it is said that the color of the underwear shouldn't be purple.

The first overload Qi Huangong had spirit of reform in The Spring and Autumn Period. He not only elevated the position of the inferior businessmen to be equal with the farmers and handicraftsman, but also showed his own preferences in the costumes without following the traditions. According to the records in Han Feizi, Qi Huangong was fond of purple dress very much. Therefore all the citizens from officials to common people would like to follow him. As a result, the price of the purple silk was up 5 times. All the subjects in Qi Dynasty were proud to dress in purple. Then in order to avoid the extravagant phenomenon, Qi Huangong took Guan Zhong's advice to claim to his subjects that he did not like purple any more. Soon, there had been a decrease of the people dressed in purple.

Till Qin and Han Dynasties, purple could be found in the costumes of the officials. The verification of this historical fact could be found in historical records. According to History of Han Dynasty, prime ministers are the officials in Qin Dynasty, and they should be given both golden seal and purple ribbon. Ribbon was used for bonding the jade wearing and chops by the officials. It had a significant meaning in identifying the position. In Collected Biographies for Fan Sui and Cai Ze of Records of the Shihchi, it has record that the prime minister has golden seal and purple ribbon in the waist. It was used to refer to the powerful position. It could be seen that the purple ribbon represents high-rank status. Even so, the negative meaning of the color purple as the secondary color still extended. In the Book of Title Explanation, it is said that purple is just the secondary color not the scared color, and it is only the deficit of the scared color to confuse people. In Wang Mang Bibliography of the History of Han, Purple frog crocks, additional days forms leap month insinuates that Wang Mang usurp the throne, in which purple means in-scared color, the frog is not the normal sound.

During the Wei, Jin, Southern and Northern Dynasties, under the background of ethnic Integration, the traditional concept about scared color and secondary color had been shocked. The typical phenomenon was that the social position of color purple had been raised and been stable gradually. At the same time, the negative meaning as the secondary color had been decreased obviously. The words bluish purple and golden purple representing high-rank officials had appeared frequently in the inscription on the gravestone in Wei, Jin, Southern and Northern Dynasties. The color purple had surpassed its own color range and become the synonyms of the royalty and the rich. On that basis, in A.D. 453, Emperor Liu Jun ordered the prohibitions on dressing purple by the knights, and the lower-rank social members shouldn't wear purple even on the edge of the costumes to maintain the authority of the ruling class.

Having gone through the changes in the former dynasties, in Sui and Tang Dynasties, it was confirmed in the regulated costume system that the color purple was for the high-rank officials. In Ce Fu Yuan Gui, Emperor Yang Guang regulated that the fifth class of officials or above should dress in purple. Till Tang Dynasty, the system for the color of costumes became more refined. During the Zhenguan period, it was regulated that purple could be dressed by the third class of officials or above, the fourth or above was red, the sixth or seventh was green, the eighth and ninth was blue. Purple then became the color dressed by the highest-rank officials. Meanwhile it was ruled that, the costume system of females should follow that of their sons or husbands, they had the same limitations. That is to say, only the wives or mothers of third-rank officials or above were allowed to dress in purple. In the recordings of Tang Dynasty, there were recordings about the royals dressed in purple. For example, in the Xin Tang Shu, both the Emperor and prince dressed purple tight pants when riding horses. There are also recordings in which infants dressed in purple costumes made by fine silk. Many corresponding prohibitions on purple costumes appear. In A.D. 674, Emperor Li Zhi ordered that the outpost officials and common people shouldn't violate the rules in the grades of the color of the costumes. Red, green or blue blouses shouldn't be dressed inside the coat, so that its social rank could not be distinguished, and it violated the etiquette. Since the edicts, the grade of the costumes should follow its rank, namely the upper level can surpass the lower, 
while the lower could not surpass the upper level. Related departments were asked to control strictly. It had not been ten years, then on A.D. 681, Emperor Li Zhi ordered that common people and businessmen were forbidden to dress in purple and red like the officials, or they would be arrested. In Tang Dynasty, purple costume was given to those deserving officials as awards, or to the leaders of other ethnics, or even to Buddhist. In A.D. 737, Emperor Li Longji had ordered to stress that red and purple were for deserving people as awards, and the rest could not dress as their will. Such repeated orders prevent the lower-rank officials or the common people to dress in purple costumes, it can be seen that the arrogation phenomenon is widespread at that time.

In remote borderland area that was far from the central government, the violations in the costume prohibitions were common. For example, in Dunhuang areas, according to the records in Dunhuang Manuscripts, the purple garments were sold in high price on the market, such as purple silk. The Japanese scholar Ikeda On wrote in his book Preliminary Exploration on the price level in ancient China that as long as the consumers would like to spend money, they could buy what they like on the market. Then we could judge that in Dunhuang areas, the prohibitions on the costumes had been neglected. Since the purple costumes represented distinguished social positions, the original materials for the purple costumes were rare. Therefore the price of the purple costumes was higher than the ordinary costumes on the market. And the changes in costume prohibition were closely related to the fast-developed manual weaving technologies in Tang Dynasty. In addition it was worth noting that in Tang Dynasty, Taoism had become state religion, and the color purple had significant symbolic meaning of the Taoism. In the literary sketches in Tang Dynasty, most immortals were dressed in purple. Therefore it had a great influence on the costume order for the ruling class.

At the beginning of Song Dynasty, the color of the official costumes followed the system in Tang Dynasty. According to the Xin Tang Shu, purple could be worn by the third class of officials or above, the fourth or fifth class was red, the sixth or seventh was green, the eighth and ninth was blue. In the literary sketches in Song Dynasty, there were records about the purple costume. It was said that since the rulers had made purple and red as the color of the costume dressed by the important officials, if the rank hadn't reached the requirements, they should not dress in purple, not only in the court, but also in their own houses. This rule was formed since Tang Dynasty, and it would be handed on.

In Song Dynasty, black was dressed by humble people, scholar-bureaucrats never wanted to wear black coarse cloth. Fan Ding in Song Dynasty once seriously reprimanded his elder brother: You are a scholar, and you should wear costumes made by fine silk, how can you wear such clothes. In ancient China, businessmen and actors were inferior to others. Emperor Zhao Jiong had ordered in A.D. 989 that both the businessmen and the actors should not dress in purple and they can only dress in black and white. Though such prohibitions had been made, since the royals all dressed in purple and all the common people followed, as a result, purple was very popular in Song Dynasty. As for the violations on the various prohibitions, according to the Collections of Anecdotes in Song Dynasty, Emperor Zhao Jiong in his advanced years had to loosen the prohibitions on purple costumes in A.D. 995. Then in A.D. 1006, Emperor Zhao Heng had given the order that the officials below the divisions shouldn't dress in black. Anyone who violated should be punished. According to the notes in Song Dynasty, in the advanced years of Emperor Zhao Zhen, the purple dyeing method employed by the craftsmen in the capital was to dye green first, then add a kind of gromwell root (a kind of dyeing media for plants), which would change the color of the textile fabrics and make it darker.

In Song Dynasty, the clamp-resist dyeing technique had been specialized through the isolation of anti-dyeing area. The costumes for the royals and armies in Song Dynasty were made through this method. It was recorded in the Song Shi, detailed records about the patterns on the costumes for honor guard of the highest scale when the emperor went on a parade. According to the records, in A.D. 1015, Emperor Zhao Heng ordered to forbid common people to dress in purple to avoid confusion with both the honor guard and the soldiers. Meanwhile, prohibitions on the production instrument had also been made. The board for dyeing was also forbidden to circulate on the market. After A.D. 1025, Emperor Zhao Zhen had made more specific prohibitions again to forbid common people except those in the capital city to wear blue, green and purple costumes with white flowers made in the way of clamp-resist dyeing. It not only avoided the confusion with the costumes for the army, but also strengthened the necessity to avoid extravagance caused by the complexities in the crafts of the clamp-resist dyeing. Till A.D. 1076, because the color purple of the official costumes was printed too dark that was similar to black, and then it was ordered that the color purple similar to black is forbidden. This prohibition seemingly reflected the protection of the high-rank officials in purple costumes; actually it implied the expansion of the prohibition on the purple costumes.

The limitations on wearing purple had been made clear in Ming Dynasty. It was recorded in the Ming Shi that in 1391 AD, Emperor Zhu Yuanzhang ordered that the costumes of the officials and the curtains shouldn't be in 
black, yellow and purple. There shouldn't be dragon and phoenix patterns on the costumes. If there was anyone who violated, even the one who made it should be blamed. Then the color purple finally became the special color of the loyalty, together with the color black and yellow that shouldn't be used by the common people. After A.D. 1458, Emperor Zhu Qizhen ordered that officials and the common people were forbidden to dress in dark black, yellow and purple costumes, the color dark black, black, yellow and so on were also forbidden. In A.D. 1504, Emperor Zhu Youtang had given orders to forbid the officials dress in dark black, yellow, purple and soaping color.

\section{Conclusion}

It can be seen that from the above mentioned historical facts, purple costumes in the social rank in ancient China had gone through a series of processes in which it was in a humble status as secondary color at first, then it rose to be the color of the costumes for the high-ranking officials, lately it became a synonym for the nobles, at last it turned to be a special and exclusive color for the royalty. Through such a process of changes, the historic environment of the politics, economy, nation, religion has an obvious influence on the ancient costumes system.

\section{References}

Cao, Zhe, \& Sun Ye. (2006, June). Study on purple clothing in the Tang Dynasty. Journal of Textile Research. Ding, Chuanjing. (1981). The Collections of Anecdotes in Song Dynasty. Beijing: Zhonghua Book Company.

Hao, Jinyang, \& Han, Jiannan. (2004, September). Refer to Colour Words of Violent on Inscription on Tablet During the Wei Jin and the North and South Dynasty. Journal of Leshan Teachers College.

Meng, Yuanlao. (1956). Dongjing Menghua Lu. Shanghai: Shanghai Classic Literature Press.

Tuotuo, A Lutu et al. (2000). History of Song Dynasty. Beijing: Zhonghua Book Company.

$\mathrm{Xu}$, Song. (1935). The Compilation of Song's Regulations. Shanghai: Dadong Book Company.

Yamamoto Masao. (1995). The Color of the Costumes and its Ideological Background in Ancient China, translated by Fanyi. Journal of Chengdu University (Social Science Edition), (4).

\section{Appendix}

The list of the prohibitions on the costumes of all dynasties

\begin{tabular}{lll}
\hline Time & Position & Content \\
\hline
\end{tabular}

Wei Jin Northern and Southern dynasties

A.D. $453 \quad$ Craftsman

Tang Dynasty

$\begin{array}{ll}\text { A.D.674 } & \begin{array}{l}\text { Official, } \\ \text { common people }\end{array}\end{array}$

A.D. 681

Common people, businessman
Emperor Liu Songxiao had ordered that craftsmen should not dress in dark reddish purple.

Emperor Li Zhi has issued edict in which officials and common people should not violate the rank of the costume color, and they should not dress blouses or coats in red, purple, green and blue inside, which would make it hard to distinguish the class and do against the rites.

All the common people were forbidden to dress in the similar purple and red costumes which were the same as officials. Elaborate funerals ignoring the rites were also forbidden, or they would be arrested.

Northern Song Dynasty
A.D. 982
Official

Following the suggestions from scholars of the Imperial Academy, Emperor Zhao Jiong said that during recent years, the officials in green coats and scholars in white coat all tended to dress in purple, it should be forbidden. They could only dress purple and white coats in their own houses. 
A.D. 989

A.D. 1025

A.D. 1062

A.D. 1076

Official

Yuan Dynasty

A.D. 1295

No

objects

Ming Dynasty

A.D. 1391

A.D. 1458

Official

A.D. 1504

Eunuch

Private, common people

A.D. 1521
Emperor Zhao Jiong had issued edicts to order that common people, businessmen and actors could only dress in white and black, instead of purple costumes.

Emperor had issued edicts to forbid the common people and subjects in the capital to wear black and brown costumes with white flowers, and blue, yellow or purple costumes with flowers.

certain Emperor had issued edicts to forbid the subjects to dress blackish purple costumes.

Emperor had issued edicts to forbid officials to court dress that is similar to purple and black.

Emperor Temur had issued edicts to forbid people to dress or made costumes in six colors such as green, red and white, brown, purple, orange red and carmine.

Emperor Zhu Yuanzhang ordered that the costumes of the officials and the curtains should not be in dark black, yellow and purple. And dragon and phoenix patterns were forbidden to be weaved, if violated, even the ones who made it would be punished.

Emperor Zhu Qizhen ordered that the officials should not dress in dark black, yellow purple, black, green, greenish yellow, brown, and bright yellow and so on.

Emperor Zhu Youtang forbade the inner court officials to dress dark black, yellow, purple costumes, greenish yellow, bright yellow and brown colors were also forbidden.
Emperor Zhu Houzhao forbade common people and soldiers to wear purple-flower coats. 